equipment) for qualified students.

Quantity refers to enrolling sufficient numbers of tuition-paying students to finance the operation of an institution-a vital part of running a private school in Japan, where almost all private institutions depend largely, and often solely, on tuition. If quality is our ideal, quantity is the only means for us to attain that goal.

\section{Boom and Bust}

The economic boom of the late 1980s and early 1990s created a sense of omnipotence-that everything was possible with Japan's wealth. The Bubble Economy, an increase in the cohort of 18-year-olds, and the belief in equal access to educational attainment led to an increase in the number of college-bound young people. Rising demand aggravated the "hard-in and easy-out" style of Japanese universities. Children were now required to study even harder to get into the university than to graduate.

The economic boom of the late 1980s and early 1990s created a sense of omnipotence that everything was possible with Japan's wealth.

To alleviate this so-called "exam hell," the Japanese government permitted institutions with sufficient resources to increase freshmen admissions until the year 2000. (In Japan, private-as well as public-institutions must follow government guidelines for freshmen admissions quotas.) Many private institutions increased admissions by 10 to 30 percent. This was also meant to fortify colleges financially.

The Bubble Economy has now burst, and the number of 18 -year-olds has dropped from a peak of 2.03 million to 1.6 million. Further declines are anticipated. If institutions continue to admit more students, it is predicted that eventually all high school graduates who apply for college will be admitted. At present, there are 990,000 18-year-olds seeking admission to a college or university; of these 790,000 will be admitted. But by 2003, the number of student applicants will be down to 750,000. As the 18-yearold age cohort shrinks, so too does the number of qualified students. Theoretically, this could mean that students who would not have qualified for college admission in 1990 would be admitted as full-time students in 2003.

Many private institutions will have to welcome even those who are not qualified academically in order to fill their classrooms (or, put more bluntly, to raise enough income to keep the institution going). A failure on the part of the universities to address the decrease in the number of students could lead to a lowering of academic requirements for high school graduation. A lessening of the competition for college entrance could generate an attitude of "Why study hard if everyone is assured of a college seat?"

\section{As the 18-year-old age cohort shrinks, so too does the number of qualified stu- dents.}

Ideally, a college president should maintain academic standards while securing the necessary revenues. At a time of declining population, income is proportional to an increase in student enrollment. But, to admit greater numbers of underqualified or less-well-prepared students necessitates offering remedial classes, which in turn may attract even greater numbers of less-qualified students. It is thus ironic that a policy intended to raise the revenues necessary to finance academic quality started a vicious cycle leading to an increase in the number of poorly prepared students.

It is a central issue today that changes introduced to strengthen private institutions are now undermining those very institutions. Presidents of private-sector institutions of higher education in Japan are now struggling to solve these and other problems.

\section{Transnational Education: An Australian Example}

\section{Grant McBurnie and Anthony Pollock}

Grant McBurnie is executive officer, Office of Deputy Vice Chancellor, International and Public Affairs at Monash University, Australia. Address: International and Public Affairs, Wellington Rd., Monash University, Clayton VIC 3168, Australia. Anthony Pollock is general manager of Monash International Pty Ltd., a wholly owned company of Monash University. E-mail: <grant.mcburnie@adm.monash.edu.au>.

$\mathrm{T}$ ransnational education is an important aspect of in ternational education. The Global Alliance for Transnational Education (GATE), an international certification body, defines it as follows:

"Transnational education ... denotes any teaching or learning activity in which the students are in a different country (the host country) to that in which the institution providing the education is based (the home country). This situation requires that national bound- 
aries be crossed by information about the education, and by staff and/or educational materials."

Transnational education is attractive to students wishing to gain a qualification granted by a foreign institution but who may be unable or unwilling to study outside their country of residence due to work, family commitments, financial, or other reasons. As a method of human resource development, it can appeal to employers and governments on financial grounds. It also appeals to education providers keen to expand their export market. Even where the term "transnational education" is generally understood, it is not always clear how it may be carried out in practice.

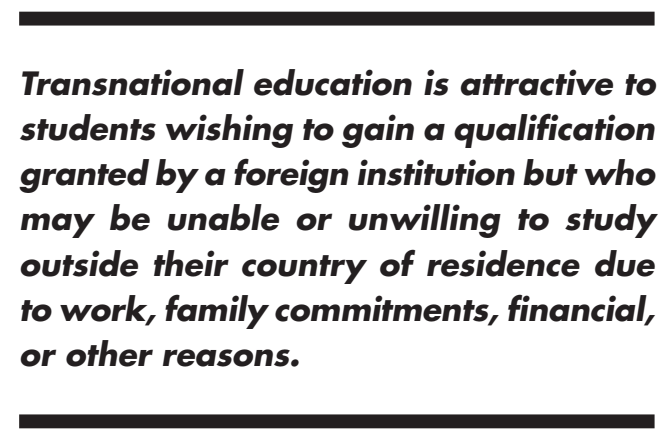

We describe below six different ways in which education is delivered transnationally. The examples are drawn from the Australian practice of providing education transnationally_chiefly, in the Asia Pacific region. While we refer to campuses and institutions, the provider could just as easily be a corporation, or a virtual university. We have modified the vocabulary for purposes of international application. For example, transnational education in Australia is generally referred to as "offshore" education, provided at "overseas" locations. Such terms are appropriate only if your nation happens to occupy an entire continent!

\section{Distance Education}

In this form of education - sometimes also referred to as "traditional," or "stand alone" distance education—students pursue independent study on a full- or part-time basis, enrolled directly within the provider institution's distance education program. Sometimes it involves travel to the provider country for course-related activities such as workshops. Course materials are transmitted from the home institution-via mail, the Internet, satellite or other means - and assignments are returned to the provider institution for correction. Examinations can usually be taken locally under supervised conditions arranged by the provider institution.

Distance education may be of limited popularity in countries where the main language is different from the language of the provider. In those cases, institutional or governmental policies may make local academic support compulsory.

\section{Locally Supported Distance Education}

Also known as "taught distance education," locally supported distance education consists of mixed mode study-that is, a combination of classroom-based and independent study, using the provider institution's distance education curriculum and materials. Students normally have access to a local study support center, which is either owned and operated by the provider institution or provided under a variety of joint-venture arrangements. Often there is some face-to-face academic input from the provider institution, in concentrated periods such as seminars and workshops. The support center would provide locally engaged staff and facilities that may include teaching space, library, and computers. Students are enrolled in the provider institution at all times and may complete the whole program through the local center or elect to transfer to the provider's home campus at some stage. Students may be enrolled part time or full time. Support centers may be private, stand-alone ventures or affiliated with existing private or public institutions.

\section{Twinning Programs}

Such programs are similar to the concept of locally supported distance education programs, except that they are fully taught programs following the same syllabus and timetable as the relevant home campus program. Students have the same materials, lectures, and examinations as their peers in the provider institution. The academic staff are usually locally engaged, but selected by the provider institution according to its usual criteria.

\section{Also known as "taught distance educa- tion," locally supported distance edu- cation consists of mixed mode study-that is, a combination of class- room-based and independent study, using the provider institution's distance education curriculum and materials.}

Within the Australian system, twinning normally means that part of the course is carried out in the host country and part in the provider country. Two years in Malaysia followed by two years in Australia is a typical format, for example.

Articulation Programs

These programs are similar to twinning programs and are 
often described as such. The primary difference, however, is that students are not enrolled in the provider institution but rather pursue a program —often leading to a local qualification of the partner organization-that is recognized for credit by the provider institution. Entry with advanced standing to the provider's home-based program is conditional on achieving a specified level of performance in the initial program. For instance, the first two years of study may lead to a diploma from the host institution. This may then be recognized for entry into the final year of the bachelor's degree in the provider's home program.

\section{Branch Campuses}

The meaning of branch campuses is ambiguous. Sometimes it is used synonymously with "twinning programs." In the strictest sense, it refers to a fully fledged campus of the provider institution that offers programs from commencement through graduation. The campus could be a joint venture, or wholly owned by the provider institution.

\section{[Articulation] programs are similar to twinning programs and are often de- scribed as such. The primary difference, however, is that students are not enrolled in the provider institution but rather pur- sue a program that is recognized for credit by the provider institution.}

\section{Franchising Arrangements}

Under such an arrangement, the provider institution grants a host in another country permission or "license" to offer the provider institution's degree under agreed conditions. The provider may then have very limited involvement in how the program is taught.

Depending upon the nature of the franchise agreement, this may sometimes be considered an unethical use of an institution's name. We know of no instance of an Australian university entering into a franchise arrangement.

This is not an exhaustive list of forms of transnational education. Instead, it briefly highlights some of the more prominent initiatives currently being practiced by Australian colleges and universities. Certainly, further options remain yet to be explored.

Note

1. See "GATE Certification Manual," page 1, available on GATE's Website at <http://www.edugate.org>.

\section{Research, Policy, and Practice in Higher Education: A UNESCO Roundtable Discussion}

\section{Glen A. Jones}

Glen A. Jones is associate professor of higher education at the Ontario Institute for Studies in Education at the University of Toronto, 252 Bloor Street West, Toronto, Ontario, M5S 1V6, Canada.

A $\mathrm{n}$ invited roundtable conference on "The Relation ship Among Research, Policy and Practice in Higher Education" was held at the University of Tokyo the first week of September 1997. Delegates included high-level policymakers in higher education, higher education researchers, and representatives of several international associations involved in higher education policy or research. Sponsored by UNESCO and the new Center for Research and Development of Higher Education (University of Tokyo), the conference provided participants with an opportunity to explore a number of extremely important themes related to this broad topic. Two recent publications provided a strong foundation for these discussions: a recent book edited by Jan Sadlak and Philip Altbach entitled Research on Higher Education at the Turn of the Century: Structures, Issues, and Trends (Garland, 1997); and the special issue of Higher Education (vol. 32, no. 4, 1996) edited by Ulrich Teichler, focusing on "The State of Comparative Research in Higher Education."

One of the central issues discussed at the conference involved the conceptual relationship between research, policy, and practice in higher education. If one assumes that higher education research should have some direct impact on policy and practice, then it is important to understand these relationships so as to increase the impact of research on both policy and practice.

\section{One of the central issues discussed at the conference involved the conceptual relationship between research, policy, and practice in higher education.}

A number of presentations examined recent policy reform processes in several countries, further illuminating the complexity of these relationships. In some situations, major policy reforms have directly or indirectly resulted from the identification of particular problems by higher education researchers. More commonly, the desire to reform higher education policy provides the stimulus for 